\title{
Miranda
}

Revue pluridisciplinaire du monde anglophone /

Multidisciplinary peer-reviewed journal on the English-

speaking world

$12 \mid 2016$

Mapping gender. Old images ; new figures

\section{New York Scene: Inside Performance Space 122}

Interview with Vallejo Gantner and Jess Edkins

\section{Margaux Szuter}

\section{(2) OpenEdition}

\section{Journals}

Electronic version

URL: http://journals.openedition.org/miranda/8338

DOI: $10.4000 /$ miranda.8338

ISSN: 2108-6559

\section{Publisher}

Université Toulouse - Jean Jaurès

\section{Electronic reference}

Margaux Szuter, "New York Scene: Inside Performance Space 122", Miranda [Online], 12 | 2016, Online since 29 February 2016, connection on 16 February 2021. URL: http://journals.openedition.org/ miranda/8338; DOI: https://doi.org/10.4000/miranda.8338

This text was automatically generated on 16 February 2021.

Miranda is licensed under a Creative Commons Attribution-NonCommercial-NoDerivatives 4.0 International License. 
New York Scene: Inside Performance

\section{Space 122}

Interview with Vallejo Gantner and Jess Edkins

Margaux Szuter

\section{Performance Space 122: website}

\section{http://www.ps122.org/}

[Figure 1]

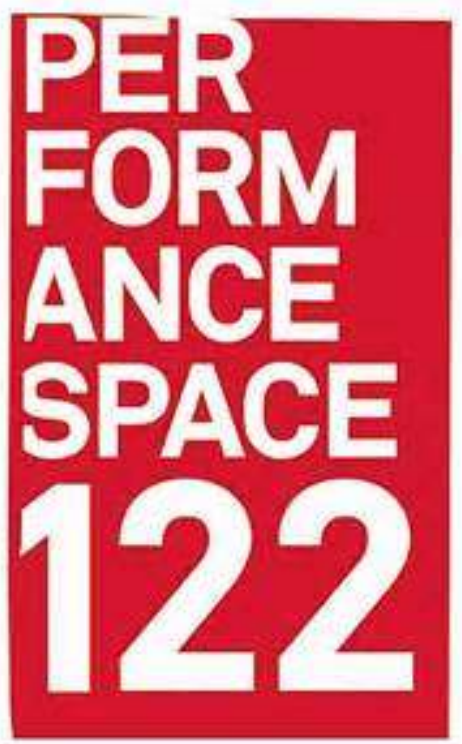

Logo P.S. 122

Credits : P.S. 122 


\section{A Brief Introduction to P.S. 122}

2 Since its creation in 1980, Performance Space 122 (P.S.122) has become one of the major organizations in New York City for the performing arts. It has always been a place where artists can challenge boundaries of live performance and that offers incomparable experiences for audiences.

3 For more than four years, P.S.122 has been facing a unique situation as it moved out its red-brick building on $1^{\text {st }}$ Avenue. Indeed, the building needed a deep inside-out renovation to continue to be the hive of the performance art scene. Partnering with other live performance venues around New York, they have decided to "take over the City," existing here and everywhere. And it seems they have succeeded! Among the different events P.S.122 organizes, the annual CoIL Festival in January is now one of the main events of the Festival Month in New York. Alongside, they have developed an international program, PS122 Global, which tours PS's artists outside the borders of the USA. ${ }^{1}$ Their second time in France in November 2015 programmed shows from ObieAward winning Andrew Schneider's YOUARENOWHERE, Annie Dorsen's YESTERDAY/ TOMORROW and THANK YOU FOR COMING: ATTENDANCE by Faye Driscoll. The shows toured from November $13^{\text {th }}$ to December $6^{\text {th }}, 2015$ at Le Tandem Théâtre d'Arras, Le Maillon-Strasbourg, Theatre National Croate in Zagreb-Croatia, Théâtre Garonne in Toulouse and le Théâtre de Gennevilliers (T2G).

\section{Biographies of the Interviewees}

4 Vallejo Gantner has been the Artistic Director of Performance Space 122 since 2005. Previously, he was Director of the Dublin Fringe Festival from 2002 to 2004, and Artistic Associate of the Melbourne Festival from 2000 to 2001. Originally from Melbourne, Vallejo has worked in a range of capacities throughout the arts in the US, Asia and Australia - as a director, writer, performer, agent, producer and programmer. He coproduced Spiegelworld from 2006 to 2008 and was a commercial producer of contemporary circus, cabaret and music across the US. More recently, he has performed in The Curator's Piece by Tea Tupajic and Petra Zank. He was an executive producer of the feature films Your Sister's Sister and Touchy Feely by Lynn Shelton, and the upcoming Men go To Battle by Zachary Treitz and Kate Lyn Sheil and directed a new concert performance at the Irish Arts Center by composer/singer Julie Feeney. Vallejo also sits on the board of directors of the National Performance Network (USA), Jianguo Pty Ltd (Aus), and Four Winds Foundation (Aus).

5 Jess Edkins is the Senior Producer at P.S.122. Before starting working with P.S.122 in 2011, she was the Producing Assistant at Whitney Live, the live performance department at the Whitney Museum of American Art, where she managed multiple projects in and out of the Whitney's galleries, including: Christian Marclay: Festival, Elizabeth Streb's ASCENSION and the re-staging of Trisha Brown's Walking on the Walls and Man Walking Down the Side of Building. As a freelance producer, she worked on projects at the Greene Space, Joyce Soho, and Alvin Ailey Studios, among many others. 


\section{Interview}

MS: If you had one word to define P.S.122, what would it be?

Vallejo Gantner: Tiring? (laughs)

Jess Edkins: Risk!

Vallejo Gantner: I would like to think that we are hard to pin down or unpredictable in the way that I don't want people to know what the experience is going to be with us. And I want to make that a virtue instead of it being a problem.

MS: Would you say this is what makes Performance Space 122 unique in New York City?

Vallejo Gantner: This is one of the things I hope. I would also like to think that we have a more global consciousness than a lot of other places. The fact that we are not in the building -not in a normal predictable space- is also something that really makes us unique. And we are more artist-focused than other organizations. But we combine that with a mission that is about audience rather than about artists. We used the audience-focus as a way of making the work of the artists easier.

MS: What kind of work do you produce?

Vallejo Gantner: We hopefully produce work that is informed by larger and bigger questions than what the larger culture is occupied with. We produce work that is generous with its audience, that is not dogmatic or dictatorial. It is the other part of the generosity: it lets the audience have agency. And of course, innovative, risky, bla bla bla... (laughs)

Jess Edkins: The kind of over-rating thought we had over the last four years is that the work we are presenting or commissioning is not just work for work-sake. We are looking at stuff that are dealing with larger ideas and provide an experience for the audience. Basically, it is not navel-gazing. We are not interested in presenting work that exists as a work itself but as something that has a larger impact beyond the stage presentation.

Vallejo Gantner: I also like the idea that the people we have been working with are obsessed with the experience the audience has. It does not mean they are massmarket or mainstream but the work they are making is actually about the way people experience it.

MS: How do you see the evolution for P.S.122 in the next five years?

Jess Edkins: Going back to the building will change a lot of things. COIL is probably just by default $75 \%$ of our programming time. Having the building will allow us to do more outside of that. I don't think that the principles and ideas -such as the life experience- are going to go away but we will be able to go further. Because right now, the structure we have created to present outside the building does require that we work with a lot of partners. And they have very different missions than what we do, so there is sometimes a compromise on how we present the work, how we are presenting the work to the audience and possibly even where we present the work! There are some venues -PS's old space included- that require some compromises and fit certain artists, and this is what we deal with in the presenting season.

Vallejo Gantner: I would hope that the evolution becomes a thing where people start to see that we have become kind of vernacular, part of the core part of the conversation. 
As long as you are aware of what is happening with us, even if you are not buying a ticket or showing up at 8 o'clock, it would mean that we did finally shake off the idea that we are marginal in some ways. Which again doesn't mean that we are mainstream or less-edgy or mass-market! But we are not marginal. It is important!

MS: What are the things you are the proudest of with PS?

Vallejo Gantner: We are alive!

Jess Edkins: We survived! (laughs)

Vallejo Gantner: There is some truth in that though. For an organization that lives as close to the edge as we do, to have moved out of the building, to have done and invented another model and kind of have done well at it and then also getting ready to move back in and raising money is kind of remarkable. We have kind of done all the things we set out to do three or four years ago, without feeling like we compromised ourselves disastrously. I think with those projects of touring in France, Croatia or Australia, we have really become global. And we have made a really strong argument that the artistic life in NYC is really dynamic, really vibrant and really significant and we have made that argument successful. I am very proud of particular projects, the staff that have come through and the way things kind of have happened.

MS: Any specific examples of projects you are specifically proud of?

Vallejo Gantner: There are lots! I am proud of all the projects but if you think about the impact we have had on someone like Okwui Okpokwasili, on Andrew Schneider, on Maria Hassabi, on Young Jean Lee, Saar Harari, Kenneth Collins, THE TEAM or Annie Dorsen [etc.], we have been there and we have been there through good work and bad work. They have been able to make, create, to fuck up also and we are still there, ready to go on another date. There are lots of careers out there that we have impacted and I am very proud of that.

MS: What do you think of the live-performance world you are working into? Do you think the work is still as interesting and risky as it was in the past or has it become redundant in terms of production and content?

Vallejo Gantner: I feel like a big shift is happening at the moment where the theater and the live performance, which were very aggressively political in the 80s and the 90s, are now still socially conscious but are coming out from a more interesting artistic perspective. There is a breakdown with the notion of work that is socially conscious which historically meant that it was bad art: there was good art and there was community work! All those boarders are breaking down in a deep way and everybody sort of recognize that we got a little bit far up around us, that there was too much navel-gazing and hopefully it is evolving. Now, the questions that are being asked are about how the audience is engaged, how we can try to find connections with them, how we can find intimacy and in doing so communicate better.

Jess Edkins: I also think that when you look back and watch those works from the 80s and 90s -or work with artists who are still working on that- there is this kind of "DIYness" and an acceptance of a "poverty" associated with how those shows got made that I think is definitely not accepted in the same way anymore. The work that is coming out of the contemporary performance scene now does involve a high degree of technology and requires months and months of rehearsals with the collaborators. That aesthetic is very noticeable. 
MS: I noticed a lot of female voices in your presenting seasons and you came in France in 2014 with three female artists: Okwui Okpokwasili, Christina Masciotti and Tina Satter. Would you call P.S.122 a feminist place? Is it a goal you set and pursue?

Jess Edkins: I don't think the goal for PS is to necessarily be feminist but when we are looking at the season as a whole, we are looking for some level of equality. It is not that we don't want to support male-work but we don't want to do it at the expense of not having female voices in the season. And that goes for dance, for theater and music.

Vallejo Gantner: It has never been a thing for us to claim that we were doing work by Women, by Latinos or this is Black work or international work even... It is just work! The issues we face here are that the culturally-specific always has to be measured by what is socially beneficial instead of the culturally-specific being artistically interesting. By culturally-specific I also mean feminist or work by women. Of course, you have to be conscious of what kind of voices you are representing and how you are reflecting it. We are always conscious of it! We don't always succeed in getting the diversity but we don't want to put the artists in a check-box. There is an idea here that we cannot hold culturally-specific work to the same level of excellence as we do other work, and there is some truth in that because "excellence" is a cultural construct. I am a straight white man from Australia so my idea of what excellence means is specific to me but the worst kind of discrimination is holding you to a lower standard. I am actually quoting G. Bush-which is a little bit embarrassing-but when he says something like the worst kind of discrimination diminishes expectation I think it is true! People call me racist because I say: "when do we start talking about excellence and about quality?" I got shattered and told that I have been racist... I was really shocked! I thought it was profoundly sad because you have to be aware of your own construct and that maybe what I think is good might not be valid and it needs to be other perspectives on it! There is not enough work in the PS season at the moment from African American artists and we have got a staff that is remarkably undiversed. It is stunning and we are very aware of it! It is a very tough issue.

MS: Since 2011, you have been facing a pretty unusual situation as you have been presenting work outside of your building in the East Village and had to pair up with many different partners across the City to do so. What are your relationships to other presenting venues, especially the Off-Off Broadway ones?

Jess Edkins: We present all of them. We have attempted or had collaborations with pretty much all of the downtown venue partners and a few uptown ones!

MS: Do you have any connections with Off-Broadway and On-Broadway venues?

Vallejo Gantner: Not really... I would actually not even describe us as "Off-Off Broadway" or "Off-Broadway" because it puts us into a hierarchy with Broadway on top as the Holy Grail. I think we should exist outside this kind of hierarchy.

Jess Edkins: I would say we are in a completely different track. One is because we don't do all theater and the Broadway trajectory is straight theater. But also because the way the artists we work with are creating work is very different.

Vallejo Gantner: In London you see a more dynamic conversation between the experimental scene and the commercial scene than you do in New York City. Here, it feels more like France in some ways where there is this other sector, the "off" commercial scene. The "Off" kind of maintains that it is some transgressive alternative when actually it is just bad commercial work that is not very successful. I 
remember going to Avignon, which used to present more experimental work than it does nowadays, and asking Vincent Baudrier -former artistic director of the Avignon Festival- about the relationship of Avignon (In) to the Off. The answer was pretty clear: they would not do someone who performed in the off because it felt really toxic. I was shocked. And sometimes it feels a bit like that here, although I don't think it is that bad!

Jess Edkins: I also just think the Broadway track has no idea of what we are doing and to a point, vice-versa. Partly for cost reasons. Most of the people from this office don't go see Broadway shows. It is a cost thing but it is also a taste.

Vallejo Gantner: I will tell you something I am actually pretty proud of. This is not always the case but in most of the work that we present, most of the performers are being paid decently. Take The Public Theater: if you are an actor in a Public Theater show and you are not a star, you earn $\$ 560$ a week. And that is the union rate! Then, you need to pay taxes and union fees. You do 8 shows a week and the ticket can be $\$ 120$. Basically, people cannot even afford to buy tickets to their own show! One of the things I am proud of is that it is pretty rare for a performer in a show we are involved in to be paid that or less...

Jess Edkins: ...If we are in charge of actually paying people! I would say that if you look at the trajectory, from 2003 when Vallejo started, the amount of what we were paying people then and the amount we are paying people now is light-years different. For instance, there is a very prominent theater artist who did her first show at P.S.122 for about $\$ 3000$ and obviously she is not getting paid that anymore. And that was in 2004 ! I don't want to say that we are paying everyone more than $\$ 500$ a week but we are definitely making a case to pay people more.

MS: Now that you are out of the building, your programming is mostly focused on your big festival in January: COIL! Do you think it has changed the way people see PS now?

Jess Edkins: I would say yes! We get great public exposure during the CoIL period. At the moment, it does constitute 75 to $80 \%$ of our programming as we are usually only doing one or two other public events outside of it that are real full-length shows. As a result, we assume unattended branding problems when people think COIL is all we do! But on the flip-side, it has really helped with the national and international recognition because there are so many presenters and colleagues in town at that period of time that, even if they are not coming to our shows, they absolutely know it is happening. ${ }^{2}$

Vallejo Gantner: I think COIL has increased the value proposition we offer to artists. It has made something where to be presented by us is more valuable than it used to be, particularly in January but I think it also affects other times of year. I feel like we get a better level of attention because, the unfortunate reality of the artistic life at the moment around the world is that we are festivalizing everything. And it has been rightly or wrongly-incredibly successful. It means you are able to create a context in a very short period of time. You are able to make an argument about this kind of work fast and in a way the press can understand and that can be spat back out to an audience. And people like it! It works even if it is not always what we would like to be! For instance, when we did Rabih Mroué last year in April at the Asia Society, I could not even get my mother to come if I paid her, it was embarrassing. ${ }^{3}$ But when we did it in January, eight months later in COIL, it was full the whole time. People go 
to stuff just because it is in COIL when they would not usually go in any other circumstances...And it drives me a little bit insane! (laughs)

MS: COIL Festival is happening all over downtown Manhattan and Brooklyn. When you are back in the building a year from now, do you want to put COIL back in the building as well? How do you want its evolution to be like?

Jess Edkins: Since 2011, we have created a structure for COIL where a lot of our partners mostly save space for us in January. But it is not always easy. We will definitely be less dependent on our partners when we will have our own space. It is going to be the main change. But I think we will still look for those partnerships. It has a benefit to the artists to be seen in front of all of those presenters. Having a whole season equally supported of all the different artistic needs -both of the audience and of the artists- would be very beneficial to everyone.

MS: Talking about the artist: who chooses whom? Do you choose artists? Or do artists choose you?

Vallejo Gantner: That is actually the first time I have been asked that question! You always want the artist you cannot get and they want the gig that they cannot have! It is actually a very mutual process. It is a funny thing because the dynamic is always thought of as the artist always being the supplicant looking for the gig to the presenter. And it is true to some extent. Unfortunately, it is true if you are unsuccessful. But as soon as you become an artist that is hitting success, the dynamic is completely reverse.

MS: Is it easier to get emerging artists then?

Jess Edkins: Yes and no. We often work with artists multiple times over the period of their careers but I think there is a point when they have to graduate from PS. They need to move on and hopefully it means to move up. They are going to bigger organizations that can support them more, that have a different audience and they can make other connections to sustain their career. Because, eventually they will go out of being emerging. But if you don't attempt to make some connections outside of whoever is supporting you as emerging, there could be problems. There are artists who routinely go back to us over and over again and we cannot support everyone. So the flip-side of that is to make sure that it is mutual but also not exclusive.

MS: When you think of your next season and start programming shows, do you have any ratio regarding theater, dance or even multimedia performances?

Vallejo Gantner: Well, yes! It has to be some of everything otherwise we would feel a bit uncomfortable I think. In the past, it has been about $40 \%$ theater, $40 \%$ dance and $20 \%$ "kook" (with music and other things). But it is not a conscious or articulate ratio.

MS: And regarding New York-based and international artists?

Vallejo Gantner: I think we have a responsibility to a local community. So obviously, it will always be the majority. In terms of ratio, I think it has been about $60-70 \% \mathrm{New}$ York City-based artists, $20 \%$ internationals and $10 \%$ nationals. So we actually have a gap: if there is a failing in that ratio, it is that we don't do enough work from other states.

Jess Edkins: And that is a sector-wide problem. Moving things -especially Americanmade work- around the country is a problem, because we cannot get funding from our own government when we can get support from foreign governments with an international work. So maybe we don't need to get a visa for a national artist -and it 
is a big expense- but we would have to cover all the other expenses incurred without any other kind of financial resources but our own. The other problem is that there are also very specific places where a work can go in the country and there are huge gaps. There are places in Seattle, in Minneapolis, there are a couple of places around the Eastern Seaboard and there is one place in Austin and then there is nothing for 3000 miles.

Vallejo Gantner: There are mid-sized cities that do not have any contemporary performing arts organizations and when you think about a place like Gent in Belgium, it has six presenters -including big ones- and it is a city that is the size of Williamsburg. Unfortunately, the culture is very concentrated in very particular cities. Hopefully it is changing a little bit. But one of the bad things for us in a way but maybe in a bigger picture it is a good thing- is that it is impossible to live in New York City, so a lot of people are moving to Detroit, Philadelphia, Minneapolis, Seattle, Portland or Austin. Those places develop a sub-culture and kind of initiate the change. If you were thinking about starting something like P.S. 122 tomorrow I would say you should go somewhere else to do it. It would be much more impactful! In New York City, there is no more money coming in but these cities are desperate for cultural activities. The support is automatically more important.

MS: You describe PS as being a place for risk. How risky do you think you are in your artistic decisions?

Jess Edkins: Risk takes many forms. Sometimes there are shows that maybe are not really risky in a big scheme but might be risky in other ways!

Vallejo Gantner: Fernando Rubio did a 7 minutes show in a bed on the pier, asking the audience to lie down in a bed with an actress telling you a sweet whispered story. ${ }^{4}$ It is not really risky in any kind of confrontation...

Jess Edkins: ... But it was risky because you are asking the audience to get in bed with someone!

Vallejo Gantner: Risk is complicated. It is not just about confrontation anymore, it is about intimacy and it is more interesting!

MS: Alongside this idea of taking over the City after leaving the building on $7^{\text {st }}$ Avenue, you also have implemented an international program to tour some artists abroad: PS122 Global. How did this program start?

Vallejo Gantner: Not to hide it but it was basically to make money!

Jess Edkins: Because our cultural funding system is unique, a lot of US companies do not make money by doing shows in the US but they do make money by going to Europe because they get pay more and there are more opportunities to make back some of their investments.

Vallejo Gantner: Because there are such limited infrastructures in the US in terms of presenting, you have to be present internationally. For the artist, it has added value to us. It was also a way for us to say we really are everywhere; we are not just in a building. Of course, it also does make a little bit of money. It is not much but it means that a lot more money is going to the artists' pockets.

MS: What was the main idea behind the creation of P.S.122 Global?

Vallejo Gantner: A lot of the Global idea came about because I was looking at the level of network that happens inside Europe and in other parts of the world: there is a very 
dynamic and constant communication between institutions and a lot of collaboration. We do not operate that way here and I wanted to start plugging us into the world in a more networked way. It was about creating a thing where we were an institution that did collaborate with other organizations internationally. And the vehicle for that became Global. There is unfortunately something we haven't really been able to properly realize as much as we should of is the reciprocity. We did do it with the Chelsea Theater in London. ${ }^{5}$ We went in 2010 and then we brought home a program of British works. We will do it with Arts House in Melbourne and hopefully we will do more of it with France.

MS: Is it complicated to bring a French show in New York?

Vallejo Gantner: No more complicated than from anywhere else. It is just the fee expectation of the French artists that are quite high...

Jess Edkins: ... Which is actually not different from any other international artist really.

MS: What about the language?

Vallejo Gantner: The language thing is not complicated, there are subtitles.

MS: How do you choose shows for the Global program?

Vallejo Gantner: This is a conversation we have with our partners. I was in France a year ago and I brought a portfolio where I said "these are seven artists that we think we are going to work within the next 12 months and this is what each of these pieces are. And here is a couple we are not working with at the moment but we did in the past and it might be possible for touring as well". It was a really interesting process. There was a show we believed that everybody was committed to and I fucked up because I let the artist think it was a sure thing as it was the impression I had. They all came, saw the show and a lot of them didn't like it and now it doesn't tour all the cities we thought it would. And then if we think of Andrew Schneider, we did not expect his show to be as polished and good as it was. We cannot always predict it. In some cases, I also try to find money to co-produce with our partners: it forces people to make a decision without having seen the work which make sometimes the decision easier because there are no getting out of it and no turning back.

MS: Why did you choose countries like France, Croatia and Australia?

Vallejo Gantner: With France, we were with this long conversation with Pascal Rambert and Nicole Martin from Théâtre de Gennevilliers (T2G) about doing something together. We already knew each other as we presented some work of Pascal in the past. Le Théâtre Garonne came in because I knew Stéphane Boitel. He was a colleague and we were excited about doing something like Global together. With Australia, my first job was actually with the Melbourne Festival. You know, we are total slut, we would do it for anybody!

Jess Edkins: Although we do have standard on how we pay people on these tours. We can fund-raise and the institutions we will partner with can fund-raise too but the main thing is that they have to respect some financial requirements. There are venues that are coming in and say that they can only offer a certain amount below our expectations. We do not necessarily say no but we tell them what they need to do for this tour and what they have to maintain if they want us to help them. But this does not happen often! 
Vallejo Gantner: For me, the more we do the better. I would love to be doing it all the time and I would love to have a full-time person managing it. I think it is exciting. Someone like Okwui Okpokwasili or Christina Masciotti and even Tina Satter, the three artists who were in France last year, they have a conversation happening there now with three different venues. They have got co-producing. It makes a big difference too. There are places where I would like to go that we haven't been, like Asia. I would really want to go in Kyoto! In China it is a bit hard because there is not really a version of us. I met a lot of producers there and they all would be commercial producers. It is tricky. And I think at some point, what I hope is a kind of project where artists are collaborating between the different places.

MS: For the 2015 edition of P.S.122 Global, you are bringing three shows to your European partners: Andrew Schneider's YOUARENOWHERE, Annie Dorsen's YESTERDAY/ TOMORROW and THANK YOU FOR COMING: ATTENDANCE by Faye Driscoll. Could you briefly introduce them?

Vallejo Gantner: All three shows are about you in the end, you the audience. That is the thing that I like about them and what I think is good about them. In the end, they are about the response that you have.

MS: This is why you want people to see these shows?

Vallejo Gantner: I want people to go and experience them. You don't see them, you experience them, you are living them. They are about how you live, about how you say and about who you are. And they all are really surprising. I love that about them.

MS: Vallejo Gantner; Jess Edkins, thank you!

\section{NOTES}

1. Bent, Eliza. "PS122's Vallejo Gantner brings the world to NY and vice versa" in American Theater Magazine, January 2015. http://www.americantheatre.org/2014/12/26/ps122s-vallejo-gantnerbrings-the-world-to-ny-and-vice-versa/

2. The Association of Performing Arts Presenters (APAP) hosts its annual conference in January, bringing many national and international presenters as well as artists showcasing their works. APAP website: http://www.apapnyc.apap365.org/apapnyc/Pages/AboutAPAPNYC.aspx

3. Rabih Mroué, 33rpm and a few seconds, co-presented by Performance Space 122, Asia Society and Pen World Voices Festival in April 2014. http://www.ps122.org/33-rpm/

4. Fernando Rubio, Everything By My Side, co-presented by Performance Space 122 with Hudson River Park and the French Institute Alliance Française (FIAF) as part of Crossing the Line Festival 2014: http://www.ps122.org/everything/

5. In the Fall of 2010, during the Sacred Festival, P.S.122 partnered with the Chelsea Theater for the first edition of P.S.122 Global. http://www.whatsonstage.com/off-west-end-theatre/news/ 10-2010/five-reasons-to-see-ps-122-and-chelsea-theatres-sa_11307.html 


\section{ABSTRACTS}

Entretien avec Vallejo Gantner et Jess Edkins, respectivement directeur et productrice artistique à Performance Space 122. Réalisé en juin 2015 à Greenpoint-Brooklyn, New York City.

Interview with Vallejo Gantner and Jess Edkins, Artistic Director and Senior Producer at Performance Space 122. Conducted in June 2015 in Greenpoint-Brooklyn, New York City.

\section{INDEX}

Keywords: American Theater, performance, Off-Off-Broadway, COIL16, PS122 Global Subjects: Theater

Mots-clés: Théâtre américain, performance, Off-Off-Broadway, COIL16, PS122 Global

\section{AUTHOR}

\section{MARGAUX SZUTER}

Les Productions Parallèles

Manager d'artistes

margaux.szuter@gmail.com 